\title{
Creating an ICT skills enhancement environment for entrepreneurs
}

\author{
Riana Steyn ${ }^{1[0000-0002-9841-2497]}$, Carina de Villiers ${ }^{1}$ and Hossana Twinomurinzi ${ }^{2}$ \\ ${ }^{1}$ Department of Informatics, University of Pretoria, South Africa \\ ${ }^{2}$ School of Computing, University of South Africa, South Africa \\ Riana.steyn@up.ac.za
}

\begin{abstract}
Entrepreneurship is seen as a primary tool in the fight against unemployment, poverty and social inequality. Although various entrepreneurial training models exist, many of these have not considered the influence of current information and communication technology (ICT), even though ICT is a contemporary tool that entrepreneurs can leverage to increase the likelihood of a successful and sustainable business. This study therefore considered one entrepreneurship model that has been successful in entrepreneurial training in South Africa, the "content model for entrepreneurship education" (E/P), and investigated how ICT could be incorporated into this. The findings of 33 participants, who had been trained using the E/P model, suggest that, while many are familiar with most of the proposed ICT software programs, they do not necessarily incorporate them in practice. Linking ICT to the business skills section of entrepreneurial training seems to be an appropriate way of making the training practically feasible for participants. However, most of the participants highlighted the need for further guidance through a mentorship programme, for example. Guidance can also take the form of graduate programmes or learnerships. The results of the study clearly show how ICT can be linked to entrepreneurial training interventions, as well as the practical aspects of such a course. They also show that entrepreneurial interventions with high-tech equipment should perhaps not be overlooked, and that the basics first should be mastered.
\end{abstract}

Keywords: Entrepreneurs, ICT, entrepreneurship education, content model for entrepreneurship, skills development

\section{Introduction}

A need to improve multisectoral issues, such as e-skilling, was identified as a means to uplift the people of South Africa in an attempt to decrease social issues like unemployment and crime. Unemployment is one of the largest concerns relating to South Africa's economic growth [1]. As many countries realise the importance of entrepreneurs and small firms in relation to their contribution to the economy [2,3], it is not surprising that one of the focus areas identified by the South African government is entrepreneurs, or more specifically, micro-enterprises, and their capability to adopt information and communication technology (ICT) innovatively. Primarily, entrepre- 
neurs have rarely undergone any form of training or received any assistance that can help them improve their businesses. This is confirmed when Pretorius, Nieman and Van Vuuren [4] state that there is an "absence of entrepreneurial education in general". Many scholars have emphasised that entrepreneurs are the engines that drive a country's economy [4-6]. Mutula and Van Brakel [5] mention that small and medium enterprises (SMEs) contribute to $60 \%$ of Europe's economic activity, and that $99 \%$ of the total number of companies in Turkey are SMEs. That SMEs are important for the country's economy is not a new phenomenon. From 1990 to 1995, 77\% of all new jobs created in the United States were created as a result of small businesses [7]. As early as the 1980s, it was noted that most European governments provided support to see how entrepreneurship could be stimulated among young people [8]. Closer to home, Barkhuizen and Bennett [9] note that, in Namibia, 20\% of employment is attributed to SMEs. Linking up with these figures and bringing the context of this paper into perspective is a study conducted by Antonites and Van Vuuren [1] in 2005, which pointed out that, in South Africa, small firms contributed 47\% to job creation, which shows that small businesses were already playing a large role in the country in 2005 , and that this role is expanding as time goes by.

The importance of these entrepreneurs successfully engaging with technology is increasing in the globally connected world in which we live. During investigations into ICT skills readiness in Botswana, it was discovered that one of the reasons for some companies not adopting ICT as they should is the limited resources available to hire and retain these skilled workers [5]. Reimenschneider et al. [7] also mention that a reason for small businesses not adopting ICT is that they immediately want to see a return on their investment and anticipated benefits; benefits that are not necessarily clear up front. The lack of education received by SMEs on the importance and benefits of computers emerged as a factor for ICT not being used in small businesses [3]. These benefits might take years before they can truly become evident, and smaller businesses cannot afford to wait so long to see if something has worked or not. Bhattacherjee and Sanford [10] mention that adoption is viewed as a one-time decision, while the long-term effects or post-adoption effects are ignored. This means that SMEs that do not raise their technology skills level will be left behind. This implies no growth for their businesses and, in many cases, no food on the table. As mentioned before, entrepreneurship is seen as a suggested solution to combat issues such as unemployment, poverty and low economic growth across the world [11]. However, what exactly entrepreneurs need to do to become successful from an ICT point of view is not very clear. This lack of skills will lead to more informal entrepreneurs or survivalists (people who work from the perspective of "what I make today puts food on my table tonight") being excluded from society in general.

The "content model for entrepreneurship education" (E/P) was analysed to see what is currently being taught in entrepreneurship. This discussion highlights the gap that exists in the training of entrepreneurs, identified as the absence of ICT training. It will be helpful to see how ICT can be incorporated into entrepreneurial training to assist in its effective adoption [8]. 
This paper will firstly discuss literature related to entrepreneurs and entrepreneurship training, followed by a discussion of the chosen methodology for the study. Findings from the data that is gathered will be analysed and discussed, before a conclusion is reached.

\section{$2 \quad$ Literature review}

\subsection{Entrepreneurs}

There does not seem to be a common definition of an entrepreneur [4]. This creates a problem, since one has to agree on a standard definition of what an entrepreneur is before one can truly conduct any entrepreneurial studies. Even though it is not a clear definition, Dhliwayo and Van Vuuren [12] make the following statement about the entrepreneurial mindset: "It denotes a way of thinking and action about business and its opportunities that captures the benefits of uncertainty". Entrepreneurship is sometimes seen as a form of creativity as "new businesses are original and useful" [13]. Antonites and Van Vuuren [1] set out to determine a general definition for an entrepreneur, and, after reviewing various authors, suggest the following definition: "An individual with the potential of creating a vision from virtually nothing". They continue to acknowledge that "the entrepreneur is able to identify an opportunity where the regular man on the street would see chaos, contradictions, ambivalence and confusion". This paper will adopt the definition by Antonites and Van Vuuren [1].

Various classifications of entrepreneurs exist according to Esselaar et al. [3], who conducted a study in 13 countries to determine ICT usage and whether it had an impact on the profitability of SMEs. They distinguish between survivalists, or informal operators, and actual small businesses. The survivalists or informal operators are the ones who try to live day by day. Thus, survivalists do not distinguish between their personal finances and their business finances. They normally consume all income generated by sales immediately and do not necessarily keep record of their actual revenue. These are the entrepreneurs who try to improve their lives and the lives of their family members, or who merely try to survive as an alternative to unemployment. These entrepreneurs are the focus of this paper, as they are the ones who will assist in uplifting people in their communities, reduce unemployment and hopefully contribute to reducing poverty.

\subsection{Content model of entrepreneurship education}

There are a number of debates around entrepreneurial education, with the main question being whether or not entrepreneurship can be taught [14]. Entrepreneurs are sometimes introduced as having "extraordinary genetic endowment" [15]. Even though this may be the case, there is a demand and call for contributions to train entrepreneurs across the world. Firstly, one has to understand that there is a difference in terminology used throughout the world. This is noted by Gibb [8], who explains that entrepreneurship education is labelled "enterprise" within the United Kingdom educa- 
tional system. This "enterprise" focuses more on individual development and not necessarily on making a profit.

Another key factor to be considered when looking at entrepreneurial training and curriculum design that incorporates ICT is the entrepreneur's belief in his or her own ability to become a successful entrepreneur [16]. This belief is the result of the entrepreneur's motivation to succeed in business. Ndubisi and Kahraman [17] point out the correlation between personality traits, such as innovation and the ability or willingness to take risks, and actual ICT usage.

The demands for entrepreneurship training are increasing and have led to various training models being developed. Various authors' viewpoints of the business skills required by an entrepreneur can be viewed in Table 1 .

Table 1. Business skills required per entrepreneur

\begin{tabular}{ll}
\hline \multicolumn{1}{c}{ Skills list } & \multicolumn{1}{c}{ Authors } \\
\hline - Business plan & Van Vuuren and Nieman [18] \\
- Financial management & \\
- Marketing & \\
- Operational skills & \\
- Human resources & \\
- Legal skills & Pretorius et al. [4] \\
- Communication & \\
- Management & \\
\hline - General management & Van Vuuren and Botha [16] \\
- Legal skills & Nieman and Bennet [19] \\
- Cash flow management & Pretorius et al. [4] \\
\hline - General management & \\
- Marketing management & \\
- Financial management & \\
- Human resource management & \\
- Production and operations management & Van Vuuren and Botha [16] \\
- Corporate communications management & \\
- Information management and e-business & \\
\hline - Lurchasing and materials management & \\
- Business plan compilation & \\
- Cash flow management &
\end{tabular}

Various entrepreneurial training models in South Africa and the rest of the world were investigated to determine the real skills needs of the entrepreneurs [4], [8], [11], [16], [18] and [20, 21]. Additional searches into entrepreneurship education training programmes led to a literature survey recently conducted by Azim and Al-Kahtani [14], based on entrepreneurship education and training, in which they summarise the content that various authors identified as required in entrepreneurship education and training (EET) programmes; they are shown in Table 2. 
Table 2. Summary of the content of an EET programme [14]

\begin{tabular}{|c|c|}
\hline Study & Contents \\
\hline Timmonset al. [22] & - Business plan \\
\hline \multirow[t]{5}{*}{ Johannisson [23] } & - The know-why (attitudes, values, motivations) \\
\hline & - The know-how (abilities) \\
\hline & - The know-who (short- and long-term social skills) \\
\hline & - The know-when (intuition) \\
\hline & - The know-what (knowledge) \\
\hline \multirow[t]{3}{*}{ Noll [24] } & $\begin{array}{l}\text { By researching customer insights, conducting a self- } \\
\text { assessment of personal creativity, conducting a feasibility } \\
\text { study and identifying various business entry strategies. }\end{array}$ \\
\hline & $\begin{array}{l}\text { By assessing personal resources and financial status, } \\
\text { researching and evaluating the risks necessary to get started, } \\
\text { writing a working business plan, and approaching others for } \\
\text { money and other resources. }\end{array}$ \\
\hline & $\begin{array}{l}\text { - By learning to allocate resources, using various marketing } \\
\text { strategies and managing money and personnel. }\end{array}$ \\
\hline \multirow[t]{3}{*}{$\begin{array}{l}\text { Garavan and } \\
\text { O'Cinneide [15] }\end{array}$} & $\begin{array}{l}\text { The formation stage: Emphasis: General business } \\
\text { knowledge content: The business world, the nature of entre- } \\
\text { preneurship, the characteristics of effective teams and the } \\
\text { nature of business transactions and activities. }\end{array}$ \\
\hline & $\begin{array}{l}\text { - The development stage: Emphasis: Skills and attitude. } \\
\text { - Content: Business planning, market selection, financial } \\
\text { planning, product identification and making financial } \\
\text { presentations. }\end{array}$ \\
\hline & $\begin{array}{l}\text { - Implementation stage: Emphasis: General knowledge and } \\
\text { attitude. Content: Financial planning, managing company } \\
\text { growth, management functions and attitudes and making the } \\
\text { transition from entrepreneur to manager. }\end{array}$ \\
\hline \multirow[t]{3}{*}{ Kourilsky [25] } & $\begin{array}{l}\text { - Opportunity recognition: The identification of unfulfilled } \\
\text { needs in the marketplace and the creation of business ideas. } \\
\text { Observation of the market, insight into customer needs, } \\
\text { invention and innovation. }\end{array}$ \\
\hline & $\begin{array}{l}\text { - Marshalling and commitment of resources: Willingness to } \\
\text { take risks as well as skills in securing outside investment. }\end{array}$ \\
\hline & $\begin{array}{l}\text { - The creation of an operating business: Financing, marketing } \\
\text { and management skills. }\end{array}$ \\
\hline \multirow[t]{4}{*}{ Rae [26] } & - Communication skills, especially persuasion \\
\hline & - Creativity skills \\
\hline & - Critical thinking and assessment skills \\
\hline & - Leadership skills \\
\hline
\end{tabular}




\begin{tabular}{|c|c|}
\hline Study & Contents \\
\hline & - Negotiation skills \\
\hline & - Problem-solving skills \\
\hline & - Social networking skills \\
\hline & - Time management skills \\
\hline \multirow[t]{3}{*}{$\begin{array}{l}\text { Hisrich and Peters } \\
\text { [27] }\end{array}$} & $\begin{array}{l}\text { - Technical skills: Include written and oral communication, } \\
\text { technical management and organising skills. }\end{array}$ \\
\hline & $\begin{array}{l}\text { - Business management skills: Include planning, decision } \\
\text { making, marketing and accounting skills. }\end{array}$ \\
\hline & $\begin{array}{l}\text { - Personal entrepreneurial skills: Include inner control, } \\
\text { innovation, risk taking and innovation. }\end{array}$ \\
\hline Vesper and Gartner & - Concept of entrepreneurship \\
\hline \multirow[t]{13}{*}{ [28] } & - Characteristics of an entrepreneur \\
\hline & - Value of entrepreneurship \\
\hline & - Creativity and innovation skills \\
\hline & - Entrepreneurial and ethical self-assessment \\
\hline & - Networking, negotiating and deal making \\
\hline & - Identifying and evaluating opportunities \\
\hline & - Commercialising a concept \\
\hline & - Developing entry strategies \\
\hline & - Constructing a business plan \\
\hline & - Finding capital \\
\hline & - Initiating the business \\
\hline & - Growing the business \\
\hline & - Harvesting strategies \\
\hline \multirow[t]{3}{*}{ Onstenk [29] } & $\begin{array}{l}\text { - Motivation, need for autonomy and independence, creativity } \\
\text { and originality, taking initiative, risk taking, looking for } \\
\text { possibilities, posing challenging objectives, self-confidence, } \\
\text { internal locus of control and endurance. }\end{array}$ \\
\hline & $\begin{array}{l}\text { - Operational management, personnel and organisation, } \\
\text { financial administration, marketing, financial management } \\
\text { and making a business plan. }\end{array}$ \\
\hline & $\begin{array}{l}\text { - Recognising business opportunities, interpretation of market } \\
\text { information and the development of customer orientation to } \\
\text { the development and effective operation of relation } \\
\text { networks and the building of an innovative organisation. }\end{array}$ \\
\hline
\end{tabular}


Throughout all these investigations, the one gap that stills exists is which ICT is required, and to effectively incorporate these required skills into the training interventions from a more practical point of view.

\subsection{Content model of entrepreneurship education}

One initiative currently running implements one of these training models in both short courses and degree programmes at an academic institution in South Africa. This training is based on the model proposed by Van Vuuren and Nieman [18] called the content model for entrepreneurship education:

$\mathrm{E} / \mathrm{P}=\mathrm{a}+\mathrm{bM}[(\mathrm{cE} / \mathrm{S} \times \mathrm{dB} / \mathrm{S})]$

Where:

$\mathrm{E} / \mathrm{P}=$ Entrepreneurial performance

$\mathrm{M}=$ Motivation

$\mathrm{E} / \mathrm{S}=$ Entrepreneurial skills

$\mathrm{B} / \mathrm{S}=$ Business skills

a, b, c and d are co-coefficients

As the main focus of this paper is not necessarily on entrepreneurship training per se, but rather on how ICT can be integrated, it will not go into detail on the equation above and will only engage in a high-level discussion of what each construct of the equation means. The co-coefficients mean that, for each construct, some basic skills exist, and thus the assumption is that these skills will feature on various levels and will have a direct influence on the construct under discussion.

The background of E/P model is supported by the expectancy theory of the motivation model that was developed in 1964 by Vroom [18]. Van Vuuren and Botha [16] state that the E/P model "is concerned with elements that drive entrepreneurial performance and was developed to guide syllabi and curriculum development". Van Vuuren and Botha [16] mention that E/P can be presented in the following way:

- Increase in productivity

- Increase in the number of employees employed

- Net value of the business

- Increase in profitability

- Completion of the first market-related transaction.

Personality and work environment can increase the performance of the entrepreneur.

Motivation is believed to be the way in which one believes that a specific system or ICT will benefit one in one's day-to-day activities [30]. Van Vuuren and Nieman [18] point out that the relationship between motivation and performance is the desire to be successful. "Motivation is seen as the entrepreneurs' level of need for achievement" [31].

Entrepreneurial skill constitutes the distinction between an entrepreneur and a manager, as these are two different things. One can train someone in a specific work domain with the relevant knowledge and skills required to perform certain tasks, such as an accountant. Life in the entrepreneurial domain cannot be taught, as there are no 
actual theories that can be tested. One can teach an entrepreneur fundamental knowledge, but there are no theories to assist in the everyday uncertainties that entrepreneurship will bring about [18].

Van Vuuren and Nieman [18] list a number of business skills that are required for an entrepreneur. It seems that these business skills are the more practical aspects of the entrepreneurial training model:

- Business plan.

- Financial management: Van Vuuren and Nieman [18] note a number of financial management skills. These are "keeping financial records, understanding taxes, as well as cash flow management, including knowledge regarding a cash budget, ratio analysis, interpreting business ratios and understanding financial statements". Although the curriculum will not ensure that whoever completes the course is a financial expert or accountant, the fundamental financial principles are important to understand.

- Marketing: A successful entrepreneur is one who knows the target market and customers' needs and can address those needs. ICT can be used to assist entrepreneurs in creating their own website, or even a presence on a social media platform, such as Facebook, which can, in turn, assist them in connecting with a much larger target audience than before.

- Operational skills.

- Human resources skills.

- Legal skills: It is not necessary for an entrepreneur to become a legal expert, but understanding basic legal aspects and terms can help them when setting up and managing various contracts, such as employment contracts, sales contracts and lease agreements. It is also beneficial to be able to draft a contract through the use of a tool, such as Microsoft Word, in order to structure documentation effectively.

- Communication: An entrepreneur must have good writing and listening skills, and must be able to talk to anybody. One way in which ICT can be used to assist entrepreneurs in enhancing their communication is by not only ensuring access to a mobile device, but also to an email account and proper email ethics, which is another gap identified in training programmes.

- Management: Leadership is one of the key aspects for an entrepreneur, as this assists entrepreneurs to maintain control over their businesses.

It is clear at this stage that the training focuses on business needs, but there is no link to ICT. The authors did a basic mapping exercise to assist the entrepreneur in deciding which ICT training to undergo. The emerging need for ICT training includes the following:

- Business plan - Microsoft Word

- Financial management - Microsoft Excel

- Marketing - website design from a template, social media

- Legal skills - Microsoft Word

- Communication - mobile device, email account 
These ICT skills are explored in this paper to determine their relevance.

\section{$3 \quad$ Methodology}

This research followed an interpretivist approach, and employed questionnaires, as well as focus groups and interviews in its survey strategy to gather data.

A course called "e-Skills for entrepreneurs", presented at an urban university, attracted 33 participants in July 2017. The authors had research funds available and subsidised a portion of the course fee, which meant that the two-day course only cost each delegate ZAR200, and included full use of the computer laboratories, as well as lunch. Although the course was initially designed for entrepreneurs who had already started their own small businesses, the authors quickly realised that there was a need for other citizens to attend such a course, as they had ideas for businesses, but they did not yet know how to realise these or how to obtain funding. During the first day of the course, the delegates were asked to complete a questionnaire to determine their skills levels, as well as the real need for technology. Throughout the two-day training, various discussions were held with these attendees and their responses were recorded as they formed part of the data analysis in the next section.

Although it seems as if the delegates could have been small business owners and not entrepreneurs, the definition introduced earlier (that an entrepreneur is able to identify an opportunity where the regular man on the street would see chaos, contradictions, ambivalence and confusion) was still the focus. The ideas identified by these potential entrepreneurs clearly showed that they could be defined as entrepreneurs.

Linking it back to the E/P, the technology that was added to the business skills construct was taught practically in the following way:

- Microsoft Excel - setting up a basic budget, and understanding basic formulas and graphs for your business

- Microsoft Word - creating a business plan that can be presented to a financial institution for possible funding, understanding basic Microsoft Word functions to allow for any documents to be drafted, writing a vision, mission and goals, and defining a basic marketing plan

- Gmail - setting up and managing an email account (including proper email ethics and responding to business requests)

- Social media as part of a marketing campaign - creating a Facebook page, managing advertising through social media, linking social media marketing to the business plan

- Free website development tools - using tools such as Weebly to create a website for the business

Except for the specific applications mentioned above, it is important to understand the participants' access to ICT and their needs in this regard.

The data was analysed using a thematic analysis approach. This approach allowed for classification into themes to see what had been left out [32]. Aronson [33] says that thematic analysis "focuses on identifiable themes and patterns of living and/or 
behaviour", which is similarly defined by Vaismoradi, Turunen and Bondas [34]. However, they continue to state that thematic analysis is a flexible tool that provides for a richer and more detailed analysis of the data, and focuses on the context being studied. The context for this paper is the survivalist entrepreneurs' access to ICT, and their ability to successfully implement it. Aronson [33] and Vaismoradi et al. [34] mention the steps involved in thematic analysis. These were compared and mapped accordingly:

- Collect data and transcribe the conversations, after which patterns can be identified [33].

- Familiarise yourself with the data [34].

- Identify all data relating to each pattern already identified [33].

- Generate initial codes [34].

- Combine and catalogue these patterns into sub-themes, thus bringing together pieces of data to form a bigger picture [33].

- Search for themes [34].

- Use emerging patterns from the themes in further discussions with the participants if needed [33].

- Review themes.

- Check if the themes work with the codes and the entire data set [34].

- Build a valid argument around the selected themes, which will develop a themed storyline in the end. This "helps the reader comprehend the process, understanding and motivation" of the participants. One should also refer to the literature to understand the context and thus incorporate the literature into the findings or themes [33].

- Define and name the themes.

- Refine the themes and the overall story [34].

- Produce the report [34].

In a thematic analysis, the importance of the theme does not necessary depend on quantifiable measures, but rather on whether the theme captures something important in relation to the overall research question [34]; in this case: What should entrepreneurs know about technology?

This research applied the thematic analysis approach based on the steps listed above. However, it is important to note that the content of the course was designed based on the initial literature review. The first three steps comprised the following:

1. Collect data and transcribe this according to patterns. Throughout the two-day course, the authors interacted with all the participants, facilitated focus group discussions and interviews, and distributed a questionnaire to ask a set of basic questions. All the questionnaires were captured and analysed, along with the focus group and interview notes.

2. Generate initial codes.

3. Combine and catalogue these patterns into sub-themes. Due to the fact that the initial questionnaire was based on the literature, the questionnaire was set up according to certain codes that had already been defined. 
Emerging patterns from the themes will be discussed in the section below, which will be followed by the conclusion.

This research paper forms part of the last step, which constitutes reporting on the findings.

\section{$4 \quad$ Findings}

Although this course was initially designed for businesses that already existed, the authors realised that potential entrepreneurs could also benefit from it. Of the 33 participants, only six already had successful businesses. However, all the others could provide a business idea. Only 12 did not specify their business ideas. The ideas, which can be seen below, prove that an entrepreneurial culture exists:

Table 3. Business ideas

\begin{tabular}{|c|c|}
\hline Briefly explain what your business or business idea is about: & Type \\
\hline $\begin{array}{l}\text { My business is going to be selling African food, for example, home- } \\
\text { cooked meals }\end{array}$ & Catering \\
\hline Catering business & Catering \\
\hline Chicken farming & $\begin{array}{l}\text { Farming and } \\
\text { agriculture }\end{array}$ \\
\hline Planning to do an internet café & ICT \\
\hline $\begin{array}{l}\text { I have registered with law to start a business. I want to buy a } \\
\text { franchise, then I need a business plan }\end{array}$ & General \\
\hline Farming, growing vegetables and chickens & $\begin{array}{l}\text { Farming and } \\
\text { agriculture }\end{array}$ \\
\hline $\begin{array}{l}\text { Fast food for everyone, we are five partners and we wish our } \\
\text { business to become a big restaurant }\end{array}$ & Catering \\
\hline I want to own a filling station & Automotive \\
\hline Hairdresser & Cosmetics \\
\hline $\begin{array}{l}\text { I buy mangos and spices. I make atchar (a South African pickle) and } \\
\text { sell it to people who own tuck shops and to households. }\end{array}$ & Catering \\
\hline $\begin{array}{l}\text { I do catering and decor for parties and weddings and other special } \\
\text { events. }\end{array}$ & $\begin{array}{l}\text { Events and } \\
\text { catering }\end{array}$ \\
\hline $\begin{array}{l}\text { I am still planning to start a beauty salon that specialises in nails and } \\
\text { eyelashes. }\end{array}$ & Cosmetics \\
\hline $\begin{array}{l}\text { Fast food and car wash, serving my customers while their cars are } \\
\text { being washed }\end{array}$ & $\begin{array}{l}\text { Automotive and } \\
\text { catering }\end{array}$ \\
\hline Mechanical engineer, engine mechanics and tyre repair & Automotive \\
\hline My business is a fashion designer & Cosmetics \\
\hline $\begin{array}{l}\text { My business is an NGO. I want to help the community, especially the } \\
\text { children who cannot afford to go to the school, to get bursaries. }\end{array}$ & Social services \\
\hline $\begin{array}{l}\text { Network and marketing business that sells healthcare } \\
\text { products and cosmetics }\end{array}$ & $\begin{array}{l}\text { Network } \\
\text { marketing }\end{array}$ \\
\hline
\end{tabular}




\begin{tabular}{ll}
\hline Briefly explain what your business or business idea is about: & Type \\
\hline Rental room & Accommodation \\
\hline Selling fast food & Catering \\
\hline We sell home-cooked meals during weekends & Catering \\
\hline
\end{tabular}

The categories for the types of businesses can be viewed in Table 4. These results give context to understand the types of entrepreneurs interviewed so that one can determine their relevance to the study.

Table 4. Business categories

\begin{tabular}{lc}
\hline Type of business & Number \\
\hline Catering & 5 \\
\hline General & 1 \\
\hline Social services & 1 \\
\hline Network marketing & 1 \\
\hline Automotive & 3 \\
\hline Events & 1 \\
\hline Farming and agriculture & 2 \\
\hline ICT & 1 \\
\hline Cosmetics & 3 \\
\hline Accommodation & 1 \\
\hline
\end{tabular}

From a gender perspective, 27 participants were female and six were male, which indicates that more women seem to be interested in entrepreneurial ventures.

Five participants did not state their age. The average age of the participants who answered the question relating to their age was 24 years, where the oldest participant was 42 years old and the youngest participant was only 15 years old.

To understand the basic availability of facilities, the participants were asked if they had electricity at home, as technology without electricity means nothing. Only one participant did not specify whether he or she had electricity. The rest of the participants indicated that they had electricity at home. This is a major benefit for ICT training.

The responses to the question prompting participants to indicate whether or not they owned a computer can be seen in Table 5 , followed by an indication of the participants' access to computers in Table 6.

Table 5. Computer ownership

\begin{tabular}{lc}
\hline Ownership of a computer & Number of responses \\
\hline I have my own computer & 8 \\
\hline My family owns a computer & 7 \\
\hline None of the above & 17 \\
\hline Not specified & 1 \\
\hline
\end{tabular}


Table 6. Access to a computer

\begin{tabular}{lc}
\hline Access to a computer & Number of responses \\
\hline I have easy access to a computer & 16 \\
\hline I have limited access to a computer & 10 \\
\hline I have no access to a computer & 6 \\
\hline Not specified & 1 \\
\hline
\end{tabular}

It is clear from Table 5 and Table 6 that most of the participants had access to a computer, although not many of them owned their own computers. Six participants did not have access to a computer, which meant that the training interventions could not focus on computers only, but also had to focus on using a mobile device for their businesses, if they had access to such a device.

This question was raised during the focus group discussion, after which participants were asked if they at least had access to a nearby internet café. Three participants indicated that they did not have access to a nearby internet café, thus implying that they had absolutely no access to a computer. One participant mentioned that receiving training in computer skills was valuable, but that the lack of access to computers afterwards was problematic, since it was difficult to continue with the skills development on an individual level after the completion of the training. It was also mentioned that if participants had access to computer facilities, they could assist other members of their communities to grow their levels of skills and knowledge.

Focusing on their mobility and connectivity, the participants were asked if they owned a mobile phone or a tablet. Only one delegate said "no", but two participants did not answer this question. Of the participants who indicated that they had mobile devices, only four had contracts with service providers, which meant that the other participants all used prepaid services to gain connectivity. If their money runs out, they will have no connectivity at all. For survivalists, this could be a major problem, as they would rather put food on the table than buy airtime. The participants who indicated that they had a mobile device were asked how many phones they were using. Eight of the participants said that they had two phones. During the focus group discussion, the participants said that they had more than one device, as it depended on who they needed to contact. The reason for this was that certain service providers' rates are cheaper if one contacts a number using the same service provider. When asked whether their device could connect to the internet, four participants said "no", two said that they could connect to the internet, one did not specify, and the other 27 participants indicated that they could access both the internet and their emails via their phones.

Table 7 shows the responses to questions relating to when participants were first introduced to computers as a means to understand what their background knowledge of technology was, and if they had equal opportunities for using technology. 
Table 7. Introduction to technology

\begin{tabular}{lc}
\hline When were you introduced to technology for the first time? & Number of responses \\
\hline During my studies after school & 10 \\
\hline Today is the first time I am going to work on a computer & 3 \\
\hline When I grew up at my school & 10 \\
\hline When I grew up in my home & 6 \\
\hline When I started to work for the first time after school & 4 \\
\hline
\end{tabular}

It was interesting to see that there was an equal split: ten participants said that they came into contact with computers during their years at school, ten participants said that they came into contact with computers during their studies, six participants said that they had computers at their homes while growing up, and four participants said that they came into contact with computers when they started working for the first time. Three participants indicated that the day of the training was the first time they had ever worked on a computer. This was alarming, as one tends to think that everybody has access to a computer.

Table 8 represents the participants' answers when asked how long they have been using computers. The majority of the participants were fairly new to the use of computers, where $63 \%$ said that they had either been using computers for less than one year or between one and two years. Only one participant did not specify the duration.

Table 8. Duration of previous computer usage

\begin{tabular}{ll}
\hline How long have you been using a computer? & Number of responses \\
\hline $1-2$ years & 5 \\
\hline $2-3$ years & 4 \\
\hline $3-4$ years & 3 \\
\hline Less than one year & 15 \\
\hline More than four years & 5 \\
\hline Not specified & 1 \\
\hline
\end{tabular}

Table 9 indicates the specific software or technology tools that participants have either used before, or that they have seen, but might not be able to use comfortably.

Table 9. Software tools or technology

\begin{tabular}{ll}
\hline Software/technology/tools & $\begin{array}{l}\text { Number of participants using or who have } \\
\text { seen software before }\end{array}$ \\
\hline Email & 26 \\
\hline Internet & 26 \\
\hline Facebook & 29 \\
\hline Twitter & 14 \\
\hline Skype & 11 \\
\hline Online shopping & 9 \\
\hline Microsoft Word & 23 \\
\hline
\end{tabular}




\begin{tabular}{ll}
\hline Microsoft Excel & 24 \\
\hline Presentation software & 22 \\
\hline Accounting software & 10 \\
\hline
\end{tabular}

It is important to note that, of the seven participants who had never used the internet before, only four had never used email. The remaining three participants had email, but had never accessed the internet before.

When considering their social media usage, only four participants did not have Facebook, but 19 participants did not have or use Twitter.

It was evident that these participants were familiar with some of the proposed technology for this course.

When the participants were asked: "Do you believe that you were given opportunities to become computer literate?", only one delegate did not specify. The rest all answered "yes". When asked to elaborate on when or where they were given these opportunities, the answers included the following:

"Teachers at my primary and high school. I was given weekly computer classes."

"I got a learnership sponsored by XXX Company."

"SAQA gave me this opportunity at the University of Pretoria."

"High school."

"Jale College at Themba, Hammanskraal, 2016 and 2017. To study IT (Information

Technology)."

The rest of the respondents (13) all said that the opportunity to attend the e-skills course was their first opportunity in this regard.

The participants were asked if they thought that digital literacy could help one grow as a human being. Two participants did not specify and the rest all said that they believed so.

Except for two participants who did not respond, all the other participants thought that digital literacy should be made available to all people, thus advocating equal opportunities for all.

When the participants were asked if they felt that there were opportunities for them to explore and expand on their digital literacy skills, five said "no", one did not specify, and the rest all said "yes".

The responses from those who said "yes" included the following:

"Many people may have greater chances of becoming employed, as digital literacy seems to now be an essential in a potential employee."

"Digital literacy makes life easy, is user friendly, accurate and saves time."

"I can further my skills in computer skills centres located in my community."

"I can open up an afternoon programme where we can offer people computer skills and more."

"I can work at many places like become a receptionist and work at any office."

"Make advertisement (digital)."

"Opportunities to get work and to have more knowledge about computers." 
"If I can explore and expand my digital literacy computer skills, I will be able to run my business very well."

"I will be able to be employed in an office such as typist, PA or receptionist."

It is interesting to note that most of the participants see some kind of digital literacy skills as their "access point" to finding employment, but most of them still focus on finding a job opportunity. It is clear that unemployment is still one of the biggest concerns relating to South Africa's economic growth, as mentioned by Antionites and van Vuuren [1]. Not many of the participants stated that it could actually grow their businesses or allow them to implement their business ideas.

Through the last question, the participants were asked if they thought it was important to be digitally literate in today's world, and why. Their responses to this question were as follows:

"Yes, because computers help us with a lot of things like researching for available jobs and getting information that you need about something."

"Yes, because it makes people access information quickly, it saves time, since, well, time is money."

"Yes, everything we do today is using technology."

Seventeen participants had similar responses.

The main outcome of the course was for the participants to each have a proper business plan, marketing plan and a basic budget, which all of them had before they left the training venue. This meant that adding the technology training to the business skills section of E/P made sense. The participants could use this to either start their businesses or apply for funding. In the two weeks following the completion of the course, the authors provided many of the participants with guidance and feedback on their business plans, as they continued to work on them via email. The authors thus became mentors for these entrepreneurs to help them finalise their business plans; a need that clearly existed in the group. This is similar to the implementation of E/P, where a ten-week mentorship programme runs after the course has been completed.

Besides the need for training participants during the two-day course, there is also a need for an extended mentorship programme to assist participants individually in order to ensure that their businesses are structured in such a way that they can apply for funding.

During the focus group discussion, participants discussed how they felt about technology and the opportunities that it held for them. The following question was asked: "Do you feel there are opportunities?"

The biggest obstacle that most of the participants noted was the current lack of employment in the country, and the subsequent need for them to start something themselves in order to survive, and to contribute to the growth of the economy.

Another problem that was raised by many of the participants was that they felt that there were some employment opportunities, but that many people were unskilled and thus could not meet the requirements for the vacancies that were available. 
Clear indication of business idea

Business not already functioning

"If I can explore and expand my digital literacy computer skills I

Business idea

will be able to run my business very well."

\begin{tabular}{|c|c|}
\hline Average age is 24 & \multirow{3}{*}{ Gender and age } \\
\hline Youngest was 15 & \\
\hline Oldest was 42 , thus need for a better life & \\
\hline Some $52 \%$ do not own a computer & \multirow{4}{*}{$\begin{array}{l}\text { Ownership of and } \\
\text { access to computers }\end{array}$} \\
\hline Most have access to a computer & \\
\hline Getting trained means nothing without access & \\
\hline Access can assist them to train other community members & \\
\hline Only two did not own a phone & \multirow{6}{*}{$\begin{array}{l}\text { Mobility and } \\
\text { connectivity }\end{array}$} \\
\hline Prefer prepaid services & \\
\hline Cheaper rates determine number of phones & \\
\hline Devices can connect to the internet & \\
\hline Four cannot connect to the internet & \\
\hline Majority have internet and email & \\
\hline Ten were introduced to computers during their school years & \multirow{12}{*}{$\begin{array}{l}\text { Background, } \\
\text { experience and skills } \\
\text { (co-coefficients }=\text { e) }\end{array}$} \\
\hline $\begin{array}{l}\text { "Teachers at my primary school and high school. I was given } \\
\text { weekly computer classes." }\end{array}$ & \\
\hline Ten were introduced during their studies & \\
\hline The majority had experience & \\
\hline The majority had less than one years' experience & \\
\hline Some $60 \%$ has two years' experience or less & \\
\hline High school & \\
\hline Learnership & \\
\hline E-skills course was the first opportunity & \\
\hline Make available to all, create equal opportunity & \\
\hline $\begin{array}{l}\text { "Digital literacy makes life easy, is user friendly, accurate and } \\
\text { saves time." }\end{array}$ & \\
\hline $\begin{array}{l}\text { "I can further my skills in computer skills centres located in my } \\
\text { community." }\end{array}$ & \\
\hline Email & \multirow{10}{*}{$\begin{array}{l}\text { Specific software, } \\
\text { applications and tools }\end{array}$} \\
\hline Internet & \\
\hline Facebook & \\
\hline Microsoft Word & \\
\hline Microsoft Excel & \\
\hline Presentation software & \\
\hline Accounting software & \\
\hline Mobile devices & \\
\hline Computers & \\
\hline "Make advertisement (digital)." & \\
\hline
\end{tabular}




\begin{tabular}{|c|c|}
\hline $\begin{array}{l}\text { "Offer tablets so that we have something to work on after- } \\
\text { wards." }\end{array}$ & $\begin{array}{l}\text { Technology or provid- } \\
\text { ing them with some } \\
\text { type of } \\
\text { resource such as a } \\
\text { tablet }\end{array}$ \\
\hline $\begin{array}{l}\text { "Yes, because it makes people access information quickly, it } \\
\text { saves time, since, well, time is money." }\end{array}$ & \multirow{4}{*}{$\begin{array}{l}\text { Opportunity, } \\
\text { learnerships or } \\
\text { mentorships }\end{array}$} \\
\hline $\begin{array}{l}\text { They feel that more learnership and internship programmes } \\
\text { should be developed to allow one to gain experience. }\end{array}$ & \\
\hline $\begin{array}{l}\text { Employment opportunities: many people are unskilled and thus } \\
\text { cannot meet the requirements for the vacancies available. }\end{array}$ & \\
\hline "Send regular updates on new features." & \\
\hline $\begin{array}{l}\text { "Many people may have greater chances of becoming employed } \\
\text { as digital literacy seems to now be an essential in a potential } \\
\text { employee." }\end{array}$ & \multirow{7}{*}{ Employment } \\
\hline $\begin{array}{l}\text { "I can open up an afternoon programme where we offer people } \\
\text { computer skills and more." }\end{array}$ & \\
\hline $\begin{array}{l}\text { "I can work at many places like become a receptionist and work } \\
\text { at any office." }\end{array}$ & \\
\hline $\begin{array}{l}\text { "Opportunities to get work and to have more knowledge about } \\
\text { computers." }\end{array}$ & \\
\hline $\begin{array}{l}\text { "I will be able to be employed in an office such as typist, PA or } \\
\text { receptionist." }\end{array}$ & \\
\hline $\begin{array}{l}\text { "Yes, because computers help us with a lot of things like re- } \\
\text { searching for available jobs and getting information that one } \\
\text { needs about something." }\end{array}$ & \\
\hline "Lack of employment in the country." & \\
\hline
\end{tabular}

They also mentioned that, for some employment opportunities, the employment sector required experience even after skills had been obtained. These people did not have experience, which meant that they could not grab these opportunities. They felt that more learnership and internship programmes should be developed to allow one to gain experience.

The participants were asked if it would help them to bridge the technology skills gap if they were given mobile devices or tablets. They felt that this would definitely help bridge the gap, although they felt that it would expose them to a security risk. However, the participants were willing to take the risk of carrying a smart phone or tablet around with them if it could help them to enhance their skills and grab opportunities.

When asked if there was anything that could be done to improve the course, the participants responded in the following way:

"Offer tablets so that we have something to work on afterwards."

"Send regular updates on new features." - linking to the mentorship programme mentioned before.

"Making presentations for my business." 
It emerged that most of the participants were trying to find employment. It was clear to the authors that the participants needed guidance. When asked how they searched for jobs, the participants responded almost in a choir with: "We Google". They were then asked what they inserted into the Google search engine, to which they responded: "Position available for jobs". This was clearly a mistake. A general discussion on how to properly look for employment opportunities was started. They were also introduced to LinkedIn and were assisted to create accounts for themselves.

As the need for employment emerged, the authors thought that perhaps one should guide them in creating their CVs as well. However, the response was a surprise. They all said that they preferred to compile a business plan to start their own businesses so that they could create their own employment opportunities.

As part of the thematic analysis, the following mapping was completed.

\section{Discussion}

It seems as if all the participants preferred the structure of the course, and could see the benefit of each topic as it related to their businesses or their business ideas. From the thematic analysis, a number of main themes emerged. These can be considered or perhaps incorporated into the course. The main themes comprised the following:

- Ownership of and access to computers

- Mobility and connectivity

- Background, experience and skills

- Technology or providing them with some type of resource, such as a tablet

- Opportunities, learnerships or mentorship

- Employment or the lack thereof

The need for mentorship or some kind of guidance to successfully implement business ideas emerged. This is a similar need identified by the E/P model of Van Vuuren and Nieman [18]. In this regard, these authors have introduced a ten-week mentoring programme. However, there is still no focus on the ICT leg of the training.

Through this study, the need for ICT skills has become clear. As one delegate rightfully said: "Because in these days, technology is useful, and if you are not familiar with it, you won't make it". However, there still seems to be a lack of opportunities for these entrepreneurs to be included in a programme in which they feel safe asking questions and confident that someone will help them. They want to take ownership of their futures and start their own businesses, but they need some guidance on how to formally go about this and how to use technology effectively in order to grow their businesses.

What is evident from the results is that one should stick to the basics when planning entrepreneurial interventions. There is no need to overcomplicate interventions with high-tech solutions, but rather to give delegates something practical that they can use to grow themselves and their businesses, and to become part of an inclusive society. 
Although these entrepreneurs should be taught the basics first, the subsequent mentorship programme must ensure that these basic features are working. The sections in bold below are the additional recommendations that emerged as needs after the training intervention:

- Microsoft Excel - setting up a basic budget, and understanding basic formulas and graphs for your business

- Microsoft Word - creating a business plan that can be presented to a financial institution for possible funding, understanding basic Microsoft Word functions to allow for any documents to be drafted, writing a vision, mission and goals, defining a basic marketing plan, providing a $\mathrm{CV}$ template for delegates to complete in their own time

- Gmail - setting up and managing an email account (including proper email ethics and responding to business requests)

- Social media as part of a marketing campaign, creating a Facebook page, managing advertising through social media, linking social media marketing to the business plan

- Free website development tools - using tools such as Weebly to create a website for the business

- Google search - using the Google search engine more effectively to look for opportunities

- LinkedIn - understanding LinkedIn, not only from a personal perspective, but from a business perspective as well

- Microsoft PowerPoint - Creating a presentation based on the business plan

- Assistance in getting access to either a tablet or a smart phone - finding a sponsorship

\section{Conclusion}

Many training interventions currently exist, and many of them are exceptional. However, not many of them focus on the ICT needs of entrepreneurs with smaller businesses, or of survivalists. One also tends to think high-tech when one starts to explore available technology opportunities, and often the basics are not even right. This paper identified the training needs of entrepreneurs from a more practical point of view, and showed the real needs of these entrepreneurs.

When looking back at E/P after incorporating technology into the business skills part of the model, it seems as if the technology and/or software tools identified make sense for the entrepreneurs. It is also clear that there is a need not only for being taught the skills, but also for getting some sort of access to resources that could help one grow one's business.

Another thing that should be considered, not necessarily as part of ICT training, but rather as part of general entrepreneurial training, is to find a way in which entrepreneurs can become learners in their specific industries for a period of time, to truly understand how their businesses should work, and then to take that knowledge and apply it to grow their own businesses. 
It is still evident, though, that unemployment is the main reason for these entrepreneurs trying to find an alternative solution or a way out of their current circumstances so that they can provide a better future for their families. Although entrepreneurship could be the answer to many unemployment and poverty issues, access to these training interventions and resources remains a problem.

\section{Bibliography}

1. Antionites, A.J. and van Vuuren, J.J., Inducing entrepreneurial creativity, innovation and opportunity-finding skills. SAJEMS, 2005. 8(3): p. 255 - 271.

2. Oke, A., Burke, G. and Myers, A., Innovation types and performance in growing UK SMEs. International Journal of operations and production management, 2007. 27(7): p. 735-753.

3. Esselaar, S., Stork, C., Ndiwalana, A. and Deen-Swarray, M., ICT usage and its impact on profitibility of SMEs in 13 African Countries, in Information and Communication Technologies and Development. 2006: Berkeley, CA p. 40 - 47

4. Pretorius, M., Nieman, G. and Van Vuuren, J.J., Critical evaluation of two models for entrepreneurial education: An improved model through integration. International Journal of Educational Management, 2005. 19(5): p. 413 - 427.

5. Mutula, S.M. and van Brakel, P., ICT skills readiness for the emerging global ditigal economy among small business in developing countries: case study of Botswana. Library Hi Tech, 2007. 25(2): p. 231-245.

6. Burn, J.M., The impact of Information technology on organisational structures. Information \& management, 1989. 16: p. 1 - 10.

7. Reimenschneider, C.K., Harrison, D.A. and Mykytyn, P.P., Understanding it adoption in small business: integrating current theories. Information \& management, 2003. 40: p. 269285.

8. Gibb, A.A., The enterprise culture and education: understanding enterprise education and its links with small business, entrepreneurship and wider educational goals. International Small Business Journal, 1993. 11(3): p. 11 - 34.

9. Barkhuizen, N. and Bennett, M., Training Adult Entrepreneurs in an Emerging Economy: The Case of Namibia. Mediterranean Journal of Social Sciences, 2014. 5(3): p. 298 - 306.

10. Bhattacherjee, A. and Sanford, C., Influence processes for information technology acceptance: an elaboration likelihood model. MIS Quarterly, 2006. 30(4): p. 805-825.

11. Botha, M., Nieman, G. and van Vuuren, J.J., Measuring the effectiveness of the women entrepreneurship programme on potential, start-up and established women entrepreneurs in south africa. South African journal of economic and management science, 2007. 10(2): p. 163-183.

12. Dhliwayo, S. and van Vuuren, J.J., The strategic entrepreneurial thinking imperative. Acta Commercii, 2007: p. 123 - 134.

13. Sarri, K.K., Bakouros, I.L. and Petridou, E., Entrepreneur training for creativity and innovation. Journal of European industrial training, 2009. 34(3): p. 270 - 288.

14. Azim, M.T. and Al-Kahtani, A.H., Entrepreneurship education and training: a Survey of Literature. Life Science journal, 2014. 11(1): p. 127 - 135.

15. Garavan, T. and O'Cinneide, B., Entrepreneurship Education and Training Programmes: A review and evaluation, Part-1. Journal of European Industrial Training, 1994. 18(8): p. 3 12. 
16. van Vuuren, J.J. and Botha, M., The practical application of an entrepreneurial performance training model in South Africa. Journal of Small Business and Enterprise Development, 2010. 17(4): p. 607 - 625.

17. Ndubisi, N.O. and Kahraman, C., Malaysian women entrepreneurs: understanding the ICT usage behaviors and drivers. Journal of Enterprise Information Management, 2005. 18(6): p. 721-738.

18. van Vuuren, J.J. and Nieman, G. Entrepreneurship Education and Training: A model For Syllabi/Curriculum Development. in 1999 International Council For Small Business Naples Conference Proceedings. 1999. Napals.

19. Nieman, G.H. and Bennet, A., eds. Business Management: A Value Chain Approach. 2nd ed. 2006, Van Schaik Publishers, Pretoria.

20. Kunene, T.R., A critical analysis of entrepreneurial and business skills in SMEs in the textile and clothing industry in Johannesburg, South Africa. 2008, University or Pretoria.

21. Hynes, B., Entrepreneurship education and training - introducing entrepreneurship into non-business disciplines. Journal of European Industrial Training., 1996. 20(8): p. 10-17.

22. Timmons, J.A., Muzyka, D.F., Stevenson, H.M. and Bygrave, W.D., Opportunity recognition: the core of entrepreneurship. Frontiers of entrepreneurial research, ed. N. Churchill. 1987, Babson Park, MA: Babson College.

23. Johannisson, B., University training for entrepreneurship: a Swedish approach. Entrepreneurship and regional development, 1991. 3(1): p. 67 - 82.

24. Noll, C.L., Planning curriculum for entrepreneurship education. Business education forum, 1993. 47(3).

25. Kourilsky, M.L., Entrepreneurship Education: Opportunity in Search of Curriculum, in Ewing Marion Kaufmann Foundation, Kansas City, MO: Center for Entrepreneurial Leadership. 1995, Ewing Marion Kaufmann Foundation, Kansas City, MO: Center for Entrepreneurial Leadership.

26. Rae, D.M., Teaching entrepreneurship in Asia: impact of a pedagogical innovation. Entrepreneurship, Innovation and Change, 1997. 6(3): p. 193 - 227.

27. Hisrich, R.D. and Peters, M.P., Entrepreneurship (4th ed.). 4th ed. 1998, Boston: Irwin McGraw-Hill.

28. Vesper, K.H. and Gartner, W.B., University entrepreneurship programs. . 2001, Los Angeles: Lloyd Grief Center for Entrepreneurial Studies, Marshal School of Business, University of Southern California: Los Angeles.

29. Onstenk, J., Entrepreneurship and vocational education. European educational research journal, 2003. 2(1): p. 74-89.

30. Venkatesh, V., Morris, M.G., Davis, G.B. and Davis, F.D., User acceptance of information technology: toward a unified view. MIS Quarterly, 2003. 27(3): p. 425-478.

31. Ladzani, W.M. and van Vuuren, J.J., Entrepreneurship training for emerging SMEs in South Africa. Journal of Small Business Management, 2002. 40(2): p. 154-161.

32. Myers, M.D., Qualitative research in business and management. 2009, SAGE Publications Ltd: London EC1Y 1SP. p. 284.

33. Aronson, J., A pragmatic view of thematic analysis. The qualitatve report, 1994. 2(1).

34. Vaismoradi, M., Turunen, H. and Bondas, T., Content analysis and thematic analysis: implications for conducting a qualitative descriptive study. Nursing and health science 2013. 15 p. 398 - 405. 
